\title{
AC 2007-1901: INTEGRATION OF ELEMENTARY ENGINEERING ELEMENTS IN THE LANGUAGE ARTS PROGRAM
}

\section{Pat Van Driessche, Douglas L. Jamerson, Jr. Elementary School}

PAT VAN DRIESSCHE is a fourth grade teacher at Douglas L. Jamerson, Jr. Elementary School Center for Mathematics and Engineering. She earned a B.S. in Elementary Education from the University of Wisconsin-Superior and her M.S. in Specific Learning and Behavior Problems from the College of St. Thomas, St. Paul, MN. Her teaching experiences include over 30 years teaching first through sixth grade and seven years in exceptional student education. Pat has presented various district trainings and is currently involved in the development of the integrated curriculum at Jamerson.

\section{Kim Parsons, Douglas L. Jamerson, Jr. Elementary School}

KIM PARSONS is the Reading Coach for Kindergarten through Third grade at Douglas L. Jamerson, Jr. Elementary School Center for Mathematics and Engineering. She earned a B.A. in Elementary Education from Florida Atlantic University and a Master of Arts in Education from the University of South Florida. Prior to her position as Reading Coach, Kim's experience included fifteen years as a classroom teacher in grades one through five. Kim has presented at various county and state venues.

\section{Chuck Parsons, Douglas L. Jamerson Jr. Elementary School}

CHARLES PARSONS is the Science Coach at Douglas L. Jamerson, Jr. Elementary School Center for Mathematics and Engineering. He earned a B.A. in Elementary Education from the University of South Florida. His experiences include over 30 years teaching in Kindergarten through fifth grade classrooms and 1 1/2 years as a resource teacher. Chuck has curriculum writing experience and has presented at various state and national venues.

\section{Robin Little, Douglas L. Jamerson Jr. Elementary School}

ROBIN LITTLE is the Engineering Coach at Douglas L. Jamerson, Jr. Elementary School Center for Mathematics and Engineering. She earned a B.A. in Elementary Education and a M.Ed. in Educational Leadership from the University of South Florida. Her experiences include over 23 years in early childhood classrooms and seven years as a teacher resource and trainer. Robin has curriculum writing experience, including a nationally published teacher resource book integrating science and literature with other areas of the curriculum.

\section{Debbie O'Hare, Douglas L. Jamerson Jr. Elementary School}

DEBORAH O'HARE is a 4th and 5th grade teacher at Douglas L. Jamerson, Jr. Elementary School Center for Mathematics and Engineering. She earned a B.A. in Elementary Education from Florida State University and has National Board Certification. In 2006, she was one of the finalists for teacher of the year for her district. Her experiences include over 21 years as a classroom teacher in all grades. Her main focus has been in the intermediate grades. Presently, she "loops" with her class from 4th to 5th grade, thus keeping them for two years. Deborah has experience writing curriculum using the Backwards Design Process and has worked with the state to create, revise and edit the math questions used on the statewide test for fifth grade.

\section{Marilyn Barger, University of South Florida}

MARILYN BARGER is the Executive Director of FL-ATE, the Florida Regional Center for Manufacturing Education housed at Hillsborough Community College. She earned a B.A. in Chemistry at Agnes Scott College, and both a B.S. in Engineering Science and a Ph.D. in Civil Engineering from the University of South Florida. She has over 16 years of experience in developing curriculum in engineering and engineering technology and is a registered professional engineer in the State of Florida. She is currently working with Douglas L. Jamerson, Jr. 
Elementary School to develop curriculum content for its Center for Mathmatics and Engineering.

\section{Richard Gilbert, University of South Florida}

RICHARD GILBERT is a professor of Chemical Engineering in the College of Engineering at the University of South Florida. He has developed educational materials for ISA (Instrument Society of America), AVS (American Vacuum Society) Science Educator's Workshop, and the National Science Foundation through a grant to develop high school science and math curriculum content. He is currently working with Douglas L. Jamerson, Jr. Elementary School to develop curriculum content for its Center for Math and Engineering. 


\section{Integration of Elementary Engineering Elements In the Language Arts Program}

\section{Introduction}

Douglas L. Jamerson, Jr. Elementary School in Pinellas County, Florida, opened three and a half years ago with a daunting challenge. Create a learning institution in a predominantly ethnically isolated inner city area that would naturally integrate the ethnicity of the student population within the school without the aid of a district assigned plan for student placement. To facilitate this challenge, the district provided key resources: 1) a new state of the art school, 2) application and subsequent Magnet School Assistance Program grant (MSAP), and 3) latitude in hiring the instructional staff. The combination of these elements has resulted in a dynamic learning community.

Jamerson has utilized the resources from a Magnet School's Assistance Program Grant to design, create and implement a standards based curriculum with the integration of essential elements of elementary engineering. In its fourth year of development, the grade level teams, with the support of specialists/coaches, and two local university professors, are producing integrated lessons for the seven units of study: Nature of Science, Gravitational Force and Resultant Motion, Electromagnetic Force, Natural Resources, Space Exploration, Life Science, and Ecosystems. The backward curriculum design process is being used to develop the integrated curriculum. This design process was developed by Grant Wiggins and Jay McTighe in Understanding by Design (ASCD, 1998). This requires teachers to answer three interrelated questions; 1) what do students need to know, understand and be able to do based on national subject area standards, Florida's Sunshine State Standards and the Pinellas County Student Expectations, 2) what is acceptable assessment evidence that they have learned the standards, 3) what specific instructional activities and learning experiences will be necessary to achieve the desired results. To approach these questions systematically, Jamerson teachers are using the Informed Design Process.

Using these questions as a guiding framework, Jamerson has designed its uniquely integrated curriculum. This required thinking "outside the box" as there is not an existing integrated engineering curriculum. This effort has to include integrating the language arts program.

\section{Elementary Language Arts Overview}

The language arts curriculum, specifically, reading and writing, can easily provide an additional support vehicle for all engineering curriculum. While engineering is the central theme for the magnet program, the school wide program is supported with research-based curricula in core subjects like reading and writing. Reading instruction is aligned with the principles of the No Child Left Behind (NCLB), Florida's Reading First initiative and utilizes the Harcourt Trophies core reading program.

Classroom teachers use the district's pacing guide based on this reading program for identifying the focus skills and strategies. These skills and strategies are incorporated into integrated reading/engineering units of study. Focus skills/strategies lessons include: phonemic awareness, 
phonics, vocabulary, and comprehension. Examples of comprehension strategies and skills include questioning, making inferences, drawing conclusions, main idea with supporting details, summarizing, cause and effect, author's purpose, sequencing, and using nonfiction text elements.

Classroom libraries have become a vital support to the reading and engineering instruction within each classroom. Initially, each classroom acquired a core library. Additional book selections have been made based on the grade level science/engineering and math units of study providing leveled reading books for student self-selection that are "just right books". Additional titles acquired also include books based on student interests.

\section{Reading and Engineering Integration}

In addition, teachers at Jamerson use grade level literature that reflects science and math concepts. Through teacher read aloud, small guided group reading instruction and independent reading, students are building their scientific and engineering background knowledge and becoming better readers. In the Natural Resources unit, the fourth grade students read The Calusas, a fourth grade Florida social studies supplemental non fiction reading resource. The Calusas were an early Floridian tribe. In reading, the students use this text to deepen their understanding of the early Calusa life using the non fiction text elements, drawing conclusions and writing a summary of how they "engineered" the use of the natural resources available to meet their needs. These language arts lessons support the concurrent engineering unit. In this unit, students learn how the Calusas built their dugout and what kinds of loads were carried. As a design project, students built clay dugouts and tested them with different loads. Students also investigated and calculated buoyant forces using their dugouts. The following table illustrates these lessons and other examples of grade level curriculum integration.

\section{Reading-Engineering Integration}

\begin{tabular}{|l|l|l|l|l|}
\hline $\begin{array}{l}\text { Grade } \\
\text { Level }\end{array}$ & $\begin{array}{l}\text { Science Unit of } \\
\text { Study }\end{array}$ & Literature Titles & $\begin{array}{l}\text { Reading Focus } \\
\text { Strategy/Skill }\end{array}$ & $\begin{array}{l}\text { Engineering } \\
\text { Connection }\end{array}$ \\
\hline K & $\begin{array}{l}\text { Gravitational Force } \\
\text { Motion }\end{array}$ & Humpty Dumpty & $\begin{array}{l}\text { Phonemic } \\
\text { awareness, } \\
\text { making } \\
\text { predictions, } \\
\text { sequencing, } \\
\text { drawing } \\
\text { conclusions }\end{array}$ & $\begin{array}{l}\text { Build and test } \\
\text { appropriate devices } \\
\text { to prevent Humpty } \\
\text { Dumpty from } \\
\text { falling off the wall } \\
\text { and ways to protect } \\
\text { him from breaking } \\
\text { if he fell off the } \\
\text { wall }\end{array}$ \\
\hline 1 & $\begin{array}{l}\text { Gravitational Force } \\
\text { and Resultant } \\
\text { Motion }\end{array}$ & John Henry & $\begin{array}{l}\text { Cause and } \\
\text { effect, main } \\
\text { and supporting } \\
\text { details, } \\
\text { comparison of } \\
\text { different } \\
\text { versions of } \\
\text { John Henry }\end{array}$ & $\begin{array}{l}\text { Build boats for } \\
\text { John Henry and test } \\
\text { them; sink and } \\
\text { float; test for push } \\
\text { and pull with } \\
\text { "blowing" to move } \\
\text { (push) their boat }\end{array}$ \\
& & & & \\
\hline
\end{tabular}




\begin{tabular}{|l|l|l|l|l|}
\hline $\begin{array}{l}\text { Grade } \\
\text { Level }\end{array}$ & Science Unit of Study & Literature Titles & $\begin{array}{l}\text { Reading Focus } \\
\text { Strategy/Skill }\end{array}$ & $\begin{array}{l}\text { Engineering } \\
\text { Connection }\end{array}$ \\
\hline 2 & Life Systems & $\begin{array}{l}\text { It Could Still Be A } \\
\text { Mammal }\end{array}$ & $\begin{array}{l}\text { Classifying } \\
\text { Describe, classify, } \\
\text { and sort the various } \\
\text { characteristics of } \\
\text { mammals using } \\
\text { pictures; find }\end{array}$ \\
\hline 3 & Space Exploration & $\begin{array}{l}\text { Magic School Bus } \\
\text { Lost in Solar } \\
\text { System }\end{array}$ & $\begin{array}{l}\text { Determining } \\
\text { fact from } \\
\text { fiction, drawing } \\
\text { conclusions, } \\
\text { summarizing }\end{array}$ & $\begin{array}{l}\text { Design a space suit } \\
\text { in order to survive } \\
\text { on a student } \\
\text { selected planet }\end{array}$ \\
\hline 4 & Natural Resources & The Calusas & $\begin{array}{l}\text { Using } \\
\text { nonfiction text } \\
\text { elements to } \\
\text { deepen } \\
\text { comprehension } \\
\text { of text, drawing } \\
\text { conclusions and } \\
\text { summarizing }\end{array}$ & $\begin{array}{l}\text { Build and test clay } \\
\text { dugouts; measure } \\
\text { mass, calculate } \\
\text { weight and } \\
\text { buoyant force }\end{array}$ \\
\hline 5 & $\begin{array}{l}\text { Electromagnetic Force } \\
\text { and Resultant Motion }\end{array}$ & Edison & $\begin{array}{l}\text { supporting } \\
\text { details, } \\
\text { predicting, } \\
\text { drawing } \\
\text { conclusions, } \\
\text { compare and } \\
\text { contrast }\end{array}$ & $\begin{array}{l}\text { Build and test } \\
\text { circuits, build and } \\
\text { test a telegraph, } \\
\text { identify changes } \\
\text { due to } \\
\text { advancements in } \\
\text { communication }\end{array}$ \\
\hline
\end{tabular}

Reading selections from the Harcourt Trophies can easily be used to support the development of engineering concepts. For example, in first grade, "The Hat", was used to discuss the "wind" as a force. Students use the Jamerson Design Process, (Plan. Design, Check, and Share), to plan, design, and build a hat that will withstand a given wind "load". After testing the hats, students shared their hat designs and the results of their tests. The reading skills addressed in this lesson focus on phonemic awareness and sequencing of events.

The sample lessons above incorporate common instructional strategies for reading. Other strategies include direct instruction, discussions in teams or partnerships, independent reading, and shared read alouds. Integrating these strategies with the engineering lessons help students build and secure vocabulary and background knowledge. Additional vocabulary reinforcement occurs during hands on learning science/engineering activities. Multiple and varied exposures with vocabulary encourages a sense of ownership, increases motivation, and fosters the development of control over student thinking and knowledge. 


\section{Writing and Engineering Integration}

Classroom teachers use writing with the science and social studies texts to support the understanding of engineering concepts. Reading and writing strategies and skills are reinforced through the use of these resources. For example, the fourth grade Natural Resources unit uses the Florida social studies text to develop background knowledge, provide a rich context for vocabulary development and understanding the curriculum connections with engineering. In this example, students work in collaborative teams as they investigate one of six early Floridian tribes. Using a graphic organizer, students gather supporting details for the main ideas about how natural resources influenced the location of the tribe, how they built their homes, how they built tools to meet their needs. After completing their research, students prepared written summaries as part of their final project using the Jameson Design Process. Students shared their information through power point presentations, dioramas, or posters.

Other examples of the writing process embedded in science/engineering units, are listed below:

*Kindergarten - blueprints with labels for Goldilocks' chair

*First Grade - science journals to record the concept of waves

*Second Grade - directions for building a tower with scaled drawings

*Third Grade - research on planets and used their information to create podcasts

*Fourth Grade - story board for their posters or power point presentations

*Fifth Grade - biography sketches of scientists, inventors and engineers

\section{Results}

The program and curriculum development teams at Jamerson have identified a set of student outcomes including: 1) the ability to use engineering design process, scientific investigation, mathematics and technology to solve real world problems, 2) acquiring knowledge and skills in reading, writing, mathematics and science to meet Florida's rigorous Sunshine State Standards, documented through the Florida Comprehensive Assessment Test (FCAT)., 3) developing skills in cooperative learning, higher order thinking, problem solving, and communication, and 4) developing grade level appropriate workplace skills. The rigorous academic program of interdisciplinary instruction supports the levels of student achievement. By integrating the reading and writing, we are able to include numerous learning opportunities to reinforce nonfiction which is a key component of the state reading assessment.

The following data tables reflect continuous growth in reading and writing at Jamerson. The table reports the percent of students scoring a level 3, 4, or 5, meeting state expectations in reading. In 2003-04, we were below the state expectations. Currently we are meeting or exceeding the state expectations.

Florida Comprehensive Assessment Test (FCAT) -- Reading Data

\begin{tabular}{|l|lll|lll|lll|}
\hline & \multicolumn{3}{|c|}{$2003-04$} & \multicolumn{3}{c|}{$2004-05$} & \multicolumn{3}{c|}{$2005-06$} \\
\hline & School & District & State & School & District & State & School & District & State \\
\hline Grade 3 & $51 \%$ & $66 \%$ & $65 \%$ & $55 \%$ & $68 \%$ & $67 \%$ & $61 \%$ & $76 \%$ & $75 \%$ \\
\hline Grade 4 & $65 \%$ & $72 \%$ & $69 \%$ & $71 \%$ & $73 \%$ & $71 \%$ & $61 \%$ & $64 \%$ & $66 \%$ \\
\hline Grade 5 & $55 \%$ & not available & $65 \%$ & $68 \%$ & $66 \%$ & $64 \%$ & $70 \%$ & $67 \%$ \\
\hline
\end{tabular}


The last table reports the percent of students meeting grade level expectations in reading based on the district's assessments in April 2006. This reading assessment is a reflection of the end of the year assessment cycle. PIAP data is used to benchmark annual student progress and drives instruction. At this time, district level data is not available.

Florida Writes Data

\begin{tabular}{|l|l|l|l|}
\hline & $2003-04$ & $2004-05$ & $2005-06$ \\
\hline Grade 4 Jamerson & $87 \%$ & $93 \%$ & $87 \%$ \\
\hline Grade 4 District & $90 \%$ & $89 \%$ & $83 \%$ \\
\hline Grade 4 State & $90 \%$ & $90 \%$ & $89 \%$ \\
\hline
\end{tabular}

The table reports the percent of students scoring a 3 or higher on the fourth grade writing test meeting state expectations. The scores for 04-05 and 05-06 indicate we are exceeding the district averages.

Pinellas Instructional Assessment Profile (PIAP) Data

\begin{tabular}{|l|l|}
\hline Grade Level & $2005-06$ \\
\hline $1^{\text {st }}$ Grade & $75 \%$ \\
\hline $2^{\text {nd }}$ Grade & $64 \%$ \\
\hline $3^{\text {rd }}$ Grade & $63 \%$ \\
\hline $4^{\text {th }}$ Grade & $68 \%$ \\
\hline $5^{\text {th }}$ Grade & $63 \%$ \\
\hline
\end{tabular}

Data indicates a positive trend. Jamerson continues to meet district expectations in reading and writing.

All of the data supports teacher observations of students using diverse classroom and library resources, and secondary resources such as the internet to extend learning within the science/engineering units of study.

\section{Concluding Remarks}

It is challenging to integrate language arts with engineering in the elementary school. This requires a lot of "thinking outside the box". Engineering itself, as an integrated discipline, requires this kind of thinking. Besides the expected science and math component, it also has language arts and social science components, making it a natural fit with the elementary curriculum.

In order to successfully integrate language arts with engineering, we have found these elements are essential: 1) vertical alignment of engineering concepts, 2) standards based curriculum, 3) instructional staff responsible for writing the curriculum, 4) professional development for the staff, and 5) outside support provided for identifying engineering concepts to include in the curriculum. 
We believe the integration of elementary engineering elements with the language arts curriculum mutually reinforce each other and increase student motivation resulting in higher student achievement.

\section{Bibliography}

Bear, D.R., M. Invernizzi, S. Templeton \& F. Johnston. Words Their Way. Linda Ashe Montgomery(ed). New Jersey:Jeffery W. Johnston (2004).

Burghart, D.M. \& M. Hacker. New York State Curriculum for Advanced Technological Education (2003).

Ellery, V. Creating Strategic Readers. Matthew W. Baker(ed). Bradenton, FL: International Reading Association (2005).

Fountas I. C \& G. S. Pinnell. Guiding Readers and Writers Grades 3-6. Lois Bridges(ed). Portsmouth, NH:Heinemann (2001).

Fountas I.C. \& G. S. Pinnell. Guided Reading Good First Teaching for All Children. Toby Gordon(ed). Portsmouth, NH:Heinemann (1996).

Galley, S.M. (2000). Portfolio as Mirrow: Student and Teacher Learning Reflected through the Standards. Language Arts 78, 121-127.

Marzano, R.J. What Works in Schools Translating Research into Action. Anonymous Alexandria, VA:Association for Supervision and Curriculum Development (2003).

Rosenshine, B. \& C. Meister. (1994). Reciprocal Teaching: A Review of the Research. Review of Educational Research 64, 479-530.

Wiggins, G., \& McTighe, J., (1998). Understanding by Design. Alexandria, VA: Association for Supervision and Curriculum Development 